\title{
Use of Ferro Frit 3110 in Developing Glazes for Omani Earthenware Clays: Evaluation of Color Quality for Ceramic Decoration in High Schools
}

\author{
Badar Almamari, Faeza Al-Thamari, Zahra Al-Zadjali, Qais Alsalhi \\ Department of Art Education, Sultan Qaboos University, Muscat, Oman \\ Email: badaralmamari@hotmail.com
}

How to cite this paper: Almamari, B., Al-Thamari, F., Al-Zadjali, Z. and Alsalhi, Q. (2020) Use of Ferro Frit 3110 in Developing Glazes for Omani Earthenware Clays: Evaluation of Color Quality for Ceramic Decoration in High Schools. Open Access Library Journal, 7: e6991.

https://doi.org/10.4236/oalib.1106991

Received: November 14, 2020

Accepted: December 13, 2020

Published: December 16, 2020

Copyright $\odot 2020$ by author(s) and Open Access Library Inc.

This work is licensed under the Creative Commons Attribution International License (CC BY 4.0).

http://creativecommons.org/licenses/by/4.0/

(c) $\underset{\mathrm{gy}}{\mathrm{i}}$ Open Access

\begin{abstract}
In this studio and laboratory research study, the suitability of several glazes for use on the earthenware clays used by local potters in the internal provinces of Oman was investigated. The aim was to develop suitable, economic glazes from local materials for use with Omani earthenware clays that could form an adequate adhesive bond with the clay surface and be used in ceramics decoration in local educational institutions. In particular, the experiments in this study mainly evaluated the use of Ferro Frit 3110 in different glazing recipes. It is a calcium- and sodium-rich frit with oxides that are stable and predictable, and it is more dependable in chemical composition than other raw materials. The final results can help to reduce the cost of importing ready-made expensive glazes from overseas for use in ceramics decoration in Omani higher educational institutions.
\end{abstract}

\section{Subject Areas}

Art, Material Experiment

\section{Keywords}

Ferro Frit 3110, Earthenware, Glaze

\section{Introduction}

It is generally accepted that red earthenware clays have been the main forming materials used by Omani potters over the course of history. Earthenware is a kind of clay that remains soft after being fired. It is easier to shape on the potter's wheel, although it is not as strong as stoneware and must be glazed in order to be watertight. The color of local Omani earthenware clay changes according 
to the firing temperature: Lower temperatures produce the typical red terracotta color, whereas higher temperatures will make the clay brighter.

One dilemma that many ceramics teachers face in their teaching in high schools is the use of glazes on non-professionally prepared earthenware clays. Glazes can show varying colors, durability, and shrinkage in the firing stage. Occasionally, ceramicists consider earthenware as a lower quality clay than stoneware and porcelain, especially because of its dark color and lower capacity to withstand high temperatures during the firing stage. For these reasons, it presents some limitations for use in art in high schools. On the other hand, there are some advantages to using earthenware clays, including their high plasticity (easily workable), lower cost for teaching purposes, and the presence of iron and other impurities, which cause the clay to reach its optimum hardness at a lower temperature $\left(950^{\circ} \mathrm{C}\right.$ and $\left.1100^{\circ} \mathrm{C}\right)$.

According to many students and ceramic materials suppliers, commercially imported glazes are extremely expensive for individual ceramicists or potters despite their widespread availability in Oman. Currently, most students in high school ceramics programs, and at various levels of education, depend on imported rather than local materials, resulting in higher costs (Almamari, 2016) [1]. On the other hand, ceramicists make their glazes recipes from scratch by mixing multiple raw materials, although some of these materials can have a high cost. To reduce the number of materials used in each recipe, ceramicists often prefer to use frits. Although frits seem to be more expensive than other raw materials used by potters and ceramicists, their advantages often outweigh their costs because they reduce costs during other stages of production (Hansen, 2017) [2]. According to Hansen (2017) [2], the use of frits instead of raw materials has many advantages, including "better fired quality, lower melting temperature, fewer defects, better clarity, smoother surface, brighter colors, faster firing, [and] lower thermal expansion." In this study, experiments were conducted on glazes made with Ferro Frit 3110 because of its stability and predictability when added to chemical glazes in comparison to other regularly used raw materials. The purpose of this investigation is to explore glazes recipes composed with a few chemical materials including Ferro Frit 3110 to replace ready-made imported glazes.

\section{Ferro Frit 3110: Description and Chemical Analysis}

According to the Oxford English Dictionary (OED), the term "frit" was first used in 1662 as "a calcinated mixture of sand and fluxes ready to be melted in a crucible to make glass" (OED, 1989) [3]. It is necessary to clarify herein what exactly is meant by frits and their contribution to glaze manufacturing. Frits are an ingredient in glaze recipes that are melted and reground prior to inclusion in the glaze slop (Hamer, 2016) [4]. Although a variety of definitions have been suggested for the term "frit," this paper will use the definition of Dodd and Murfin (1994) [5], who described frits as materials used in ceramic glazes that have 
been fused, quenched, and granulated. They are considered an important part of compounding enamels and ceramic glazes. Basically, frits are combined raw materials that are mixed, fired, melted, crushed, and ground into a powder. The use of frits can decrease the toxicity of raw materials such as lead, barium, and zinc; reduce the fusion point of glazes; and avoid the volatilization of unstable substances.

In particular, Ferro Frit 3110 is a high calcium and sodium and low alumina frit fired in the range of cone 6 . Its melting range is approximately $760^{\circ} \mathrm{C}$ $925^{\circ} \mathrm{C}\left(1400^{\circ} \mathrm{F}-1700^{\circ} \mathrm{F}\right)$, and it is regularly used in crystal glazes. The biggest advantage of using this frit is that it is considered a storehouse of oxides that are both stable and predictable. The term "Frit 3110-2" is a relatively new name for "Ferro Frit 3110," which is a soft sodium borosilicate frit for use in glazes. According to Hansen (2017) [2], it has high thermal expansion and, consequently, is useful for substitution in glazes that show shivering and is also as a body flux to substitute for feldspar. Chemically, it contains $\mathrm{SiO}_{2}, \mathrm{Al}_{2} \mathrm{O}_{3}, \mathrm{~B}_{2} \mathrm{O}_{3}, \mathrm{Na}_{2} \mathrm{O}, \mathrm{CaO}$, and $\mathrm{K}_{2} \mathrm{O}$. Table 1 shows its chemical analysis.

According to the Safety Data Sheet (SDS) produced by Ferro (one of the best factories worldwide specialized in making frits), this frit considered a "non-hazardous substance or mixture." In the case of inhalation, the user must seek out fresh air and, in case of skin contact, the user must immediately wash it off with soap and plenty of water. In the case of swallowing, the user should seek medical advice (SDS, 2020).

\section{Laboratory Tests}

Most of the experiments were executed at the Sultan Qaboos University Ceramic Lab (SQUCL) from September to November in 2020 using clay and dry materials available at the SQUCL. The researchers used a test tile numbering system beginning with "Glaze test" followed by the number of the test. For the clear base test, the name remained as "Glaze Test \#," and once colorants are added, a small letter was added as an identifier (e.g., Glaze Test \#a, Glaze Test \#b, etc.).

To start testing, we used the glaze recipe of Sekino-Bove (2009) which considered as (Glaze Test 1), specifically her N501 transparent glossy and crackle (Sekino-Bove, 2009) [6]. The recipe is shown in Table 2.

Then, we conducted more tests using the same chemical items at different percentages. A total of 7 samples were evaluated and fired in the electric kiln (oxidation atmosphere) in the range of cone $5\left(1196^{\circ} \mathrm{C}\right.$, Group A) and at a lower

Table 1. Chemical analysis of Ferro Frit 3110 (source: glazy.org).

\begin{tabular}{ccccccc}
\hline Frit Type & $\begin{array}{c}\mathrm{SiO}_{2} \\
\mathrm{Silica}\end{array}$ & $\begin{array}{c}\mathrm{Al}_{2} \mathrm{O}_{3} \\
\text { Aluminum } \\
\text { oxide }\end{array}$ & $\begin{array}{c}\mathrm{B}_{2} \mathrm{O}_{3} \\
\text { Boron } \\
\text { trioxide }\end{array}$ & $\begin{array}{c}\mathrm{Na}_{2} \mathrm{O} \\
\text { Sodium } \\
\text { oxide }\end{array}$ & $\begin{array}{c}\mathrm{K}_{2} \mathrm{O} \\
\text { Potassium } \\
\text { oxide }\end{array}$ & $\begin{array}{c}\mathrm{CaO} \\
\text { Calcium } \\
\text { oxide }\end{array}$ \\
\hline $\begin{array}{c}\text { Ferro Frit 3110 } \\
\text { Total }\end{array}$ & 69.80 & 3.70 & 2.60 & 15.29 & 2.29 & 6.31 \\
\hline
\end{tabular}


Table 2. Glaze recipe N501 transparent glossy and crackle by Sekino-Bove (2009) [6].

\begin{tabular}{|c|c|}
\hline \multicolumn{2}{|c|}{ Glaze Test 1} \\
\hline Chemical Item & Percentage (\%) \\
\hline Ferro Frit 3110 & $90 \%$ \\
\hline EPK Kaolin & $10 \%$ \\
\hline \multicolumn{2}{|c|}{ Glaze Test 1a } \\
\hline Chemical Item & Percentage (\%) \\
\hline Ferro Frit 3110 & $90 \%$ \\
\hline EPK Kaolin & $10 \%$ \\
\hline +P4179 (egg yellow stain) & $2 \mathrm{~g}$ \\
\hline \multicolumn{2}{|c|}{ Glaze Test 2} \\
\hline Chemical Item & Percentage (\%) \\
\hline Ferro Frit 3110 & $85 \%$ \\
\hline EPK Kaolin & $15 \%$ \\
\hline \multicolumn{2}{|c|}{ Glaze Test $2 \mathrm{a}$} \\
\hline Chemical Item & Percentage (\%) \\
\hline Ferro Frit 3110 & $85 \%$ \\
\hline EPK Kaolin & $15 \%$ \\
\hline+ chrome oxide (green) & $2 \mathrm{~g}$ \\
\hline \multicolumn{2}{|c|}{ Glaze Test 3} \\
\hline Chemical Item & Percentage (\%) \\
\hline Ferro Frit 3110 & $80 \%$ \\
\hline EPK Kaolin & $20 \%$ \\
\hline \multicolumn{2}{|c|}{ Glaze Test 3a } \\
\hline Chemical Item & Percentage (\%) \\
\hline Ferro Frit 3110 & $80 \%$ \\
\hline EPK Kaolin & $20 \%$ \\
\hline +magnesium dioxide & $2 \mathrm{~g}$ \\
\hline \multicolumn{2}{|c|}{ Glaze Test 4} \\
\hline Chemical Item & Percentage (\%) \\
\hline Ferro Frit 3110 & $75 \%$ \\
\hline EPK Kaolin & $25 \%$ \\
\hline \multicolumn{2}{|c|}{ Glaze Test $4 \mathrm{a}$} \\
\hline Chemical Item & Percentage (\%) \\
\hline Ferro Frit 3110 & $75 \%$ \\
\hline EPK Kaolin & $25 \%$ \\
\hline +yellow stain & $4 \mathrm{~g}$ \\
\hline
\end{tabular}


temperature in the range of cone $6\left(1000^{\circ} \mathrm{C}\right.$, Group B). The tested recipes are listed at following (Figure 1 and Figure 2).

\section{Firing Atmosphere}

We used an electric kiln. It is known that electric kiln firings are commonly oxidizing (excluding a small amount of reduction materials from the burn-off of organics in the clay body of ceramics pieces, sulfurs, and gums, which are usually added to glazes). Once the kiln door is shut very tightly, these materials can consume all of the oxygen in the kiln, creating a reducing atmosphere. The utilized pottery craft kilns have vents that draw air into them to burn off the combustibles

\section{Group A}

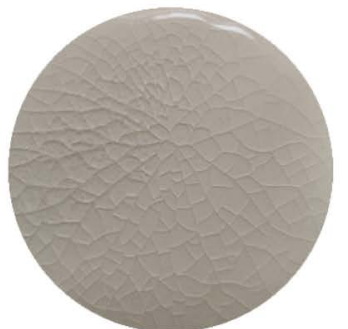

Test 1: Cone $5\left(1196^{\circ} \mathrm{C}\right)$

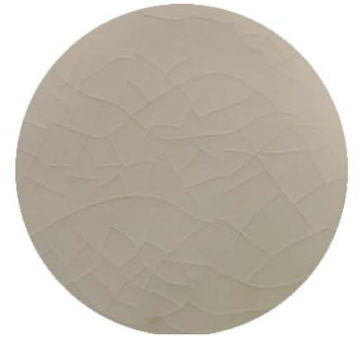

Test 2: Cone $5\left(1196^{\circ} \mathrm{C}\right)$

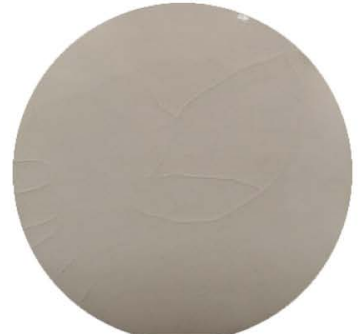

Test 3: Cone $5\left(1196^{\circ} \mathrm{C}\right)$

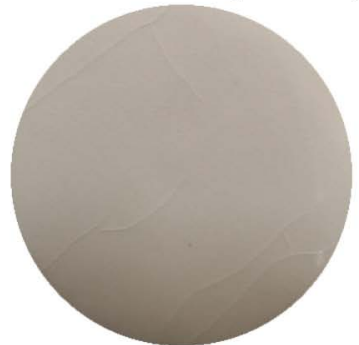

Test 4: Cone $5\left(1196^{\circ} \mathrm{C}\right)$

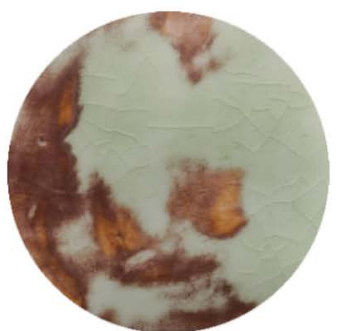

Test 1a: Cone $5\left(1196^{\circ} \mathrm{C}\right)$

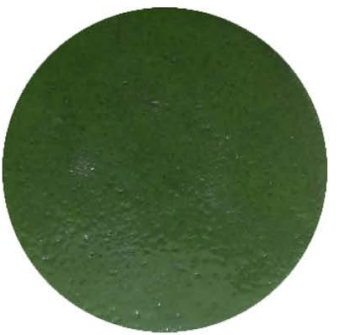

Test 2a: Cone $5\left(1196^{\circ} \mathrm{C}\right)$

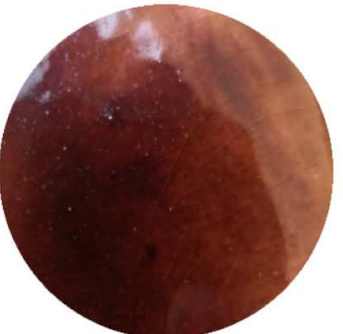

Test 3a: Cone $5\left(1196^{\circ} \mathrm{C}\right)$

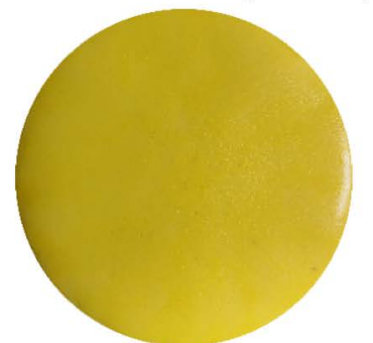

Test 4a: Cone $5\left(1196^{\circ} \mathrm{C}\right)$

Figure 1. Test results of glazes fired in an electric kiln at a temperature of $1196^{\circ} \mathrm{C}$ (Cone 5). 


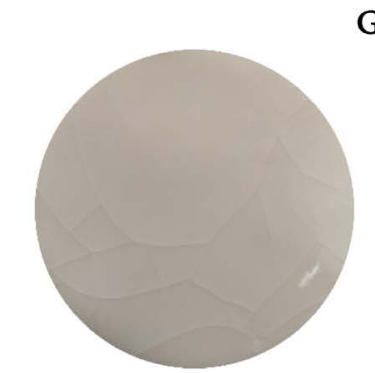

Test 1: Cone $06\left(1000^{\circ} \mathrm{C}\right)$

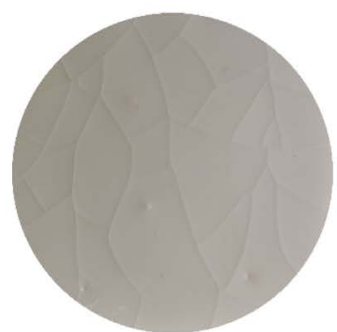

Test 2: Cone $06\left(1000^{\circ} \mathrm{C}\right)$

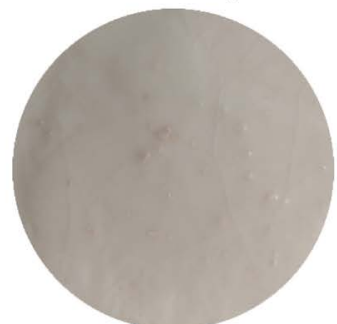

Test 3: Cone $06\left(1000^{\circ} \mathrm{C}\right)$

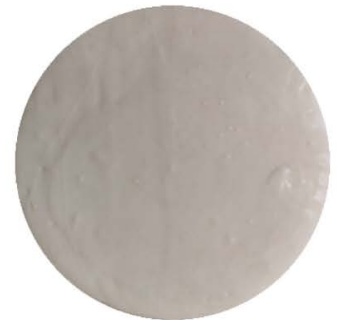

Test 4: Cone $06\left(1000^{\circ} \mathrm{C}\right)$
Group B

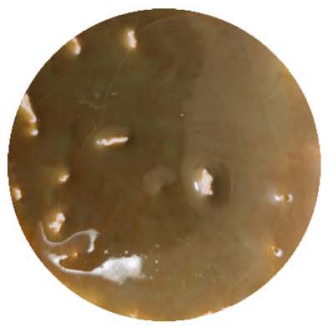

Test 1a: Cone $06\left(1000^{\circ} \mathrm{C}\right)$

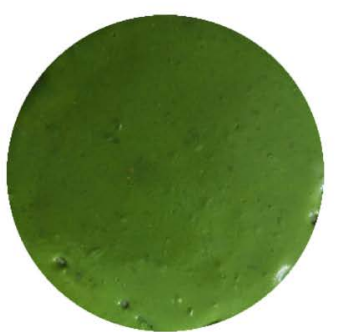

Test 2a: Cone $06\left(1000^{\circ} \mathrm{C}\right)$

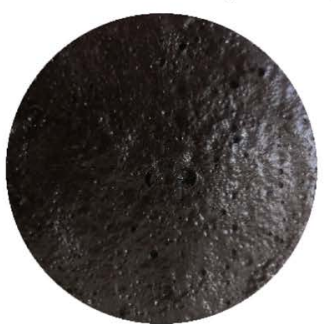

Test 3a: Cone $06\left(1000^{\circ} \mathrm{C}\right)$

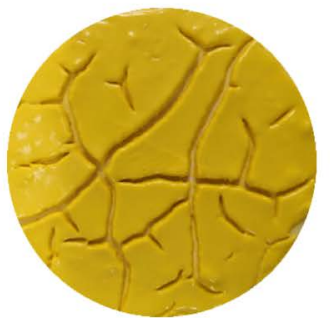

Test 4a: Cone $06\left(1000^{\circ} \mathrm{C}\right)$

Figure 2. Test results of glazes fired in an electric kiln at a temperature of $1000^{\circ} \mathrm{C}$ (Cone 06).

and produce a cleaner firing, yielding brighter glazes. The chart below (Figure 3) shows the firing processes for both groups of tests (A \& B):

\section{Tests Analysis}

As the images of the tests show, there is a significant difference between the two groups. Strong evidence of smoother textures (which may be desirable for commercial ceramics) was found for the tests of Group A. In particular, tests $2 \mathrm{a}, 3 \mathrm{a}$, and $4 \mathrm{a}$ showed a very smooth texture, and none of the well-known glaze defects, such as crazing, shivering, crawling, pin holing, and blistering, appeared in these glaze recipes. In contrast, the same recipes fired at temperatures of $1000^{\circ} \mathrm{C}$ (in Group B at nearly $200^{\circ} \mathrm{C}$ lower compared to Group A), many defects appeared. 


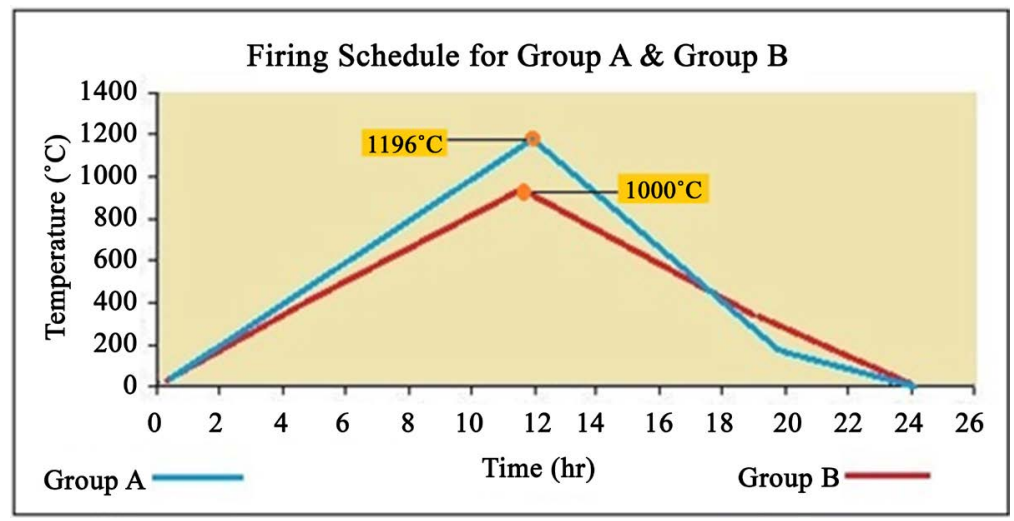

Figure 3. Firing Schedule for Groups A and B.

Table 3. Results of the tests according to presence or absence of defects and glaze quality.

\begin{tabular}{|c|c|c|c|c|c|c|}
\hline Group & Test Code & Crazing & Shivering & Crawling & Pin holing & Blistering \\
\hline \multirow{8}{*}{$\begin{array}{c}\mathrm{A} \\
1196^{\circ} \mathrm{C}\end{array}$} & 1 & $x$ & $\checkmark$ & $\checkmark$ & $\checkmark$ & $\checkmark$ \\
\hline & 1a & $x$ & $\checkmark$ & $\checkmark$ & $\checkmark$ & $\checkmark$ \\
\hline & 2 & $x$ & $\checkmark$ & $\checkmark$ & $\checkmark$ & $\checkmark$ \\
\hline & $2 a$ & $\checkmark$ & $\checkmark$ & $\checkmark$ & $\checkmark$ & $\checkmark$ \\
\hline & 3 & $x$ & $\checkmark$ & $\checkmark$ & $\checkmark$ & $\checkmark$ \\
\hline & $3 a$ & $x$ & $\checkmark$ & $\checkmark$ & $\checkmark$ & $\checkmark$ \\
\hline & 4 & $x$ & $\checkmark$ & $\checkmark$ & $\checkmark$ & $\checkmark$ \\
\hline & $4 a$ & $\checkmark$ & $\checkmark$ & $\checkmark$ & $\checkmark$ & $\checkmark$ \\
\hline \multirow{8}{*}{$\begin{array}{c}\text { B } \\
1000^{\circ} \mathrm{C}\end{array}$} & 1 & $x$ & $\checkmark$ & $\checkmark$ & $\checkmark$ & $\checkmark$ \\
\hline & 1a & $x$ & $\checkmark$ & $x$ & $\checkmark$ & $\checkmark$ \\
\hline & 2 & $x$ & $\checkmark$ & $\checkmark$ & $\checkmark$ & $\checkmark$ \\
\hline & $2 \mathrm{a}$ & $\checkmark$ & $\checkmark$ & $\checkmark$ & $\checkmark$ & $\checkmark$ \\
\hline & 3 & $x$ & $\checkmark$ & $\checkmark$ & $\checkmark$ & $\checkmark$ \\
\hline & $3 a$ & $\checkmark$ & $\checkmark$ & $\checkmark$ & $x$ & $\checkmark$ \\
\hline & 4 & $\checkmark$ & $\checkmark$ & $\checkmark$ & $\checkmark$ & $\checkmark$ \\
\hline & $4 a$ & $x$ & $\checkmark$ & $x$ & $\checkmark$ & $\checkmark$ \\
\hline
\end{tabular}

$\checkmark=$ Defect not found; $\mathbf{X}=$ Defect found.

For example, tests 1a and $4 \mathrm{a}$ showed a crawling defect. To summarize the final tests, Table 3 shows the results according to the qualities of the glazes or, concretely, the presence or absence of certain defects.

\section{Conclusion and Recommendations for Art Schools}

One of the more significant findings to emerge from this study is that many of the tested glazes are suitable for use in ceramic glazing in schools. These findings have significant implications for understanding how potters, ceramicists, and teachers in schools of art can reduce the numbers of chemical materials in glaze 
recipes, which can considerably reduce the costs of materials. But, it is worth remembering that additional experiments on other frits would help to establish a greater degree of accuracy on this matter. So, further research could also be conducted on the effectiveness of the other frits mentioned in the final table.

\begin{tabular}{cc}
\hline No. & Name of Frit \\
\hline 1 & Lead Bisilicate Frit \\
2 & Borax (E) Frit \\
3 & Calcium Borate Frit \\
4 & Borax (J) Frit \\
5 & Alkaline Standard Frit \\
6 & High Alkali (T) Frit \\
7 & Low Borosilicate Ferro \\
8 & Standard Borosilicate Ferro \\
9 & High Alkaline Ferro Frit \\
10 & High Borosilicate Ferro Frit \\
11 & White Zircon Borax Frit \\
\hline
\end{tabular}

\section{Acknowledgements}

By using the university glazing laboratory, this research was supported by Sultan Qaboos University. I would like to thank my colleagues from the Department of Art Education, whose insight and expertise greatly assisted the research.

\section{Conflicts of Interest}

The authors declare no conflicts of interest regarding the publication of this paper.

\section{References}

[1] Badar, A. (2016) Developing Ceramic Textured Matt Glazes Using Omani Plant Ash: The Contributions of Art Education Teachers. Journal of Arts \& Humanities, 5, 12-18. https://doi.org/10.18533/journal.v5i12.1047

[2] Hansen, T. (n.d.) https://digitalfire.com/glossary/frit

[3] Weiner, E.S. and Simpson, J.A. (1989) The Oxford English Dictionary. Clarendon Press, Oxford.

[4] Hamer, F. and Hamer, J. (2016) The Potter's Dictionary: Of Materials and Techniques. Bloomsbury Academic, London.

[5] Dodd, A. and Murfin, D. (1994) Dictionary of Ceramics. The Institute of Materials, London.

[6] Sekino-Bove (2009) 15 Tried and True Cone 6 Glaze Recipes. https://ceramicartsnetwork.org/freebies/free-guides/15-tried-true-cone-6-glaze-reci pes/ 